\title{
Company Performance Predictions By Agency Cost, Earning Management Using the Z-Score (Case Study in Indonesia)
}

\section{Nisrul Irawati, Isfenti Sadalia, and Lisa Marlina}

Department of Management, Faculty of Economics and Business, Universitas Sumatera Utara, Indonesia

\section{Abstract}

Investors play an important role by spending their money in the capital market. Without investors, the stock market do trade securities trading. In choosing a company, investors will evaluate the best condition of the company. So the aim of this research is to investigate whether the agency cost and earning management will give an impact to financial distress. The research object is the company listed in Indonesian Capital Market from 2012 to 2016. The regression analysis used to test the hypothesis

Corresponding Author: Nisrul Irawati nisrulirawati@yahoo.com

Received: 29 August 2018 Accepted: 18 September 2018 Published: 11 November 2018

Publishing services provided by Knowledge E

(c) Nisrul Irawati et al. This article is distributed under the terms of the

Attribution License, which permits unrestricted use and redistribution provided that the original author and source are credited.

Selection and Peer-review under the responsibility of the ICOI-2018 Conference Committee

\section{G OPEN ACCESS} was applied only to the final sample of 22 firms at the end of the sample period from 2012 to 2016. This study used the Modified Jones Model to measure discretionary accruals as earning management. And the dependent variables Z-score served as substitutes for financial distress. The hypothesis was tested using a regression model. The first independent variable operating expense ratio as substitutes the agency cost has a negative significant on financial distress. The smaller amount of agency cost will impact the Z-score to increase. This showed that if the Z-score is higher, it will mean that the company is in the area of no financial distress. Then, the second variable earning management has negative relationship but insignificant on financial distress.

Keywords: agency cost, earning management, financial distress

\section{Introduction}

Capital Markets should be efficient which help investors to evaluate every listed company. Investors play an important role by spending their money in the capital market. Without investors, the stock market cannot trade securities trading.

Recently, there have been an increasing in the amount of investors in Indonesia. According to PT Kustodian Sentral Efek Indonesia, the number of investors in the Indonesian capital market rose $25.24 \%$ by the end of 2017 compared to the end of 2016. (CNN Indonesia, 2017). In doing the investment, every investor should bear the risk of their investment decision as the balance of getting a return so that investors 
desperately need the financial information of the company as a material to analyze the level of future profits that will be obtained from the investment will be done.

The information disclosed in the financial statement use by investor to make their own decision. Therefore, managers are obliged to provide information about the company's condition to the investors. The information submitted by managers sometimes does not match the actual company conditions because managers tend to report something to maximizes their utility. This is known as information asymmetry that can give managers an opportunity to practice earnings management (Richardson, 1998). The earning management that intentionally created by managers will eradicate the reliability and quality of the financial information. According to Decow and Skinner (2000), the most powerful tools to manage earnings are discretionary accruals. However, GAAP allows certain discretion in making choices and estimates in determining accruals basis accounting.

Consequently, investors will be misled about the company's economic performance by this earning management practice [5]. Investors who have chosen failed company will suffer more severe losses than those of company just having poor performances so that detection of earning management in the years preceding bankruptcy becomes important. Bankruptcy usually begins with the situation where a company face financial distress. Financial distress is a condition when the company is unable to cope with the debt holder's obligation. A company under financial distress can incur costs related to the situation, such as more expensive financing. There are two interest groups in a company which each group has its own goals. These groups consist of principal and agent. Agency costs are a type of internal cost that arises from, or must be paid to, an agent acting on behalf of a principal. These costs arise because of core problems, such as conflict of interest between shareholders and management. Shareholders wish for management to run the company in a way that increases shareholders value, while management may wish to grow the company in ways that maximize their personal power and wealth that may not be in the best interests of shareholders. Based on a disagreement between management and shareholders as to what actions are in the best interest of the business, agency costs result. Agency costs include any expense that is associated with managing the relationship and resolving differing priorities.

\section{Literature Review}




\subsection{Financial distress}

Financial distress in enterprises has long been an issue of concern to governments and the investing public. A significant and persistent decline in a company's financial performance may eventually result in insolvency, making investors and creditors suffer considerable financial loss.

The Altman z score is used to predict the likelihood of a business will get into financial distress. The formula is based on information found in the income statement and balance sheet of an organization; as such, it can be readily derived from commonly available information. Given the ease with which the required information can be found, the z score is a useful metric for an outsider such as investor who has access to a company's financial statements. In its original form, the z score formula is as follows:

$$
Z=0.012 \times 1+0.014 \times 2+0.033 \times 3+0.006 \times 4+0.999 \times 5 .
$$

Where

$$
\begin{aligned}
& X_{1}=\text { working capital/total assets, } \\
& X_{2}=\text { retained earnings/total assets, } \\
& X_{3}=\text { earnings before interest and taxes/total assets, } \\
& X_{4}=\text { market value equity/book value of total liabilities, } \\
& X_{5}=\text { sales/total assets, and } \\
& Z=\text { overall index }
\end{aligned}
$$

The rules is that the lower the score, the higher the odds are that a company is headed for bankruptcy. A z-score of lower than 1.8, in particular, indicates that the company is heading for bankruptcy. Companies with scores above 3 are unlikely to enter bankruptcy. Scores in between 1.8 and 3 lie in a gray area.

\subsection{Agency cost}

According to the theory of the relationship between principals (owners) and agents (managers) - principal-agent theory - owners hires managers to run the firm on their behalf. The social and private costs of an agent's action due to incomplete alignment of the agent's and owner's interests were brought to attention by the seminal contributions of Jensen and mackling (1976) on agency costs. Agency costs are a kind of transaction costs connected with way in which a firm is organized. Agency costs are real costs which depend on legal regulations and the willingness of people to sign contracts, among others. They are always present in all companies and at every level 
of management and, as pointed out earlier, are always borne by current shareholders ([9], p. 891). The purpose of incurring them is to assure that managers will act in the capital suppliers' best interests. The measurement of agency costs was still depending on proxy variables. According to literature, there were seven proxy variables suggested to measure agency costs: they are total asset turnover [1]; Singh and Davidson (2003), operating expense to sales ratio [1], administrative expense to sales ratio; Singh and Davidson (2003), earnings volatility, advertising and r \& d expense to sales ratio, floatation cost [9]. Therefore, Wang (2010), suggest that operating expense ratio is all the expense that relate to the company operation.

$$
\text { Operating Expense Ratio }=\frac{\text { Operating Expense }}{\text { Net Sales }}
$$

\subsection{Earning management}

Earnings management has been defined in many different ways: for example, for Healy and Wahlen (1999), earnings management occurs when managers use judgment in financial reporting and in structuring transactions to alter financial reports to either mislead stakeholders about the underlying economic performance of the company or otherwise to influence contractual outcomes that depend on reported accounting numbers.

To capture managers' earnings management behavior, this research use measures of discretionary accruals as calculated by the modified jones model. The definition of accruals ( $A C C$ ) as the difference between net income $(\mathrm{NI})$ and operating cash flows $(O C F)$ and estimate equation (1) below for all firms in each year to derive the nondiscretionary component of total accruals (NDA).

$$
\mathrm{ACC}_{t}=\alpha_{0}\left(\text { 1/Assets }_{t-1}\right)+\alpha_{1}\left(\Delta \text { Sales }_{t}-\Delta \text { Debtors }_{t}\right)+\alpha_{2} \mathrm{PPE}_{t}+\varepsilon_{t}
$$

Where, $\Delta$ sales is the change in operating revenue from $t-1$ to year $t, \Delta$ debtors is the change in debtors from year $t-1$ to year $t$ and $p p e$ is property, plant and equipment. $D A$ is the residual from equation (3), that is, $D A=A C C-N D A$. [4]

\section{Research Method}

Our basic approach is to identify firms which likely to become financially troubled in periods of research. This research use secondary data, which consist of the financial statement component of 22 companies, were collected from Indonesian Capital Market 
period 2012-2016. The analysis will be covered into descriptive analysis and regression analysis. For regression analysis, the random are effects taken into consideration.

The model was proposed in this research which financial distress will predicted by Agency Cost and Earning Management. In a mathematical expression, it may state:

$$
Y_{1} \text { ZScore }=\beta_{0}+\beta_{2} \text { OER }++\beta_{1} E M \varepsilon
$$

Whereas, Z-Score $=$ Financial Distress

OER = Operating Expense Ratio as substitutes of Agency Cost

EM = Earning Management

\section{Result}

TABLE 1: Descriptive analysis.

\begin{tabular}{l|c|c|c|}
\hline & Z_SCORE & EM & OER \\
\hline Mean & 2.839047 & 0.037993 & 0.114158 \\
\hline Median & 2.631079 & 0.009736 & 0.071716 \\
\hline Maximum & 9.273589 & 2.906904 & 0.429978 \\
\hline Minimum & 0.714509 & -0.244799 & 0.013491 \\
\hline Std. Dev. & 1.383009 & 0.259091 & 0.109270 \\
\hline Skewness & 1.514174 & 10.38354 & 1.662627 \\
\hline Kurtosis & 6.609285 & 115.6738 & 4.630316 \\
\hline Jarque-Bera & 122.0881 & 72196.59 & 75.43383 \\
\hline Probability & 0.000000 & 0.000000 & 0.000000 \\
\hline Sum & 374.7542 & 5.015029 & 15.06882 \\
\hline Sum Sq. Dev. & 250.5655 & 8.793776 & 1.564120 \\
\hline Observations & 132 & 132 & 132 \\
\hline Source: Author's calculation $(2018)$. & & \\
\hline
\end{tabular}

From Table 1 show the result of financial distress proxy by Z-Score for this research that the maximum Z-Score 9.273589, the minimum Z-Score is 0.714509 . It showed that there are still some companies tend to head to have financial distress if it based on the Z-score evaluation. Based on Z-Scores said that companies with score above 3 are unlikely headed to bankruptcy. However, mostly of the companies listed are in the healthy condition with $Z$ score 0.714509 . Earning management that exist in the listed company in Indonesia has maximum EM 2.906904, the minimum EM -0.244799. there is no single company that does not do earning management but in different way. Finally, it's the Operating Expense Ratio show that the listed company in Indonesia has a maximum value of 0.429978 and the minimum value is 0.013491 . 
TABLE 2: Regression analysis.

Dependent Variable: $Y_{i} Z$-Score

Method: Least Squares

Date: $03 / 30 / 18$

Sample: 1132

Include observations: 132

\begin{tabular}{l|c|c|c|c}
\hline Variable & Coefficient & Std. Error & t-Statistic & Prob. \\
\hline C & 3.277337 & 0.168701 & 19.42687 & 0.0000 \\
\hline EM & -0.317021 & 0.448343 & -0.707096 & 0.4808 \\
\hline OER & -3.733828 & 1.063072 & -3.512302 & 0.0006 \\
\hline R-squared & 0.090104 & $\begin{array}{l}\text { Mean dependent var. S.D. dependent } \\
\text { var. Akaike info criterion Schwarz } \\
\text { criterion Hannan-Quinn criter. }\end{array}$ & 2.839047 \\
\hline $\begin{array}{l}\text { Durbin-Watson stat. } \\
\text { R-susted }\end{array}$ & & & & \\
\hline S.E. of regression & 1.329418 & & & 1.383009 \\
\hline $\begin{array}{l}\text { Sum squared } \\
\text { resid. }\end{array}$ & 227.9885 & & & 3.429825 \\
\hline Log likelihood & -223.3685 & & & 3.495343 \\
\hline F-statistic & 6.387224 & & & 3.456449 \\
\hline Prob(F-statistic) & 0.002264 & & & \\
\hline Source: Author's calculation (2018). & & & \\
\hline
\end{tabular}

Based on the random-model regression, we can formulate that

$$
Z-S C O R E=3.277337--3.733828 O E R--0.317021 E M .
$$

As the multiple regression analysis reveals that Operating Expense Ratio has a negative significant impact on financial distress Z-Score represent by probability $<0.05$. The standard coefficient of operating expense ratio is -3.733828 and $t$-statistic -3.512302 . It means that for every unit increase of OER will decrease Z-Score by -3.733828 . Furthermore, the result shows that there is no significant relationship between earning management and financial distress Z-Score. It shows by probability of earning management $p=0.4808>0.05$. In order to test the hypothesis, the general rule is that if that $p$-value $<0.05$ reject $\mathrm{Ho}$ and if $p$-value $>0.05$ reject $\mathrm{H}_{1}$.

\section{Discussion}

According to the empirical result, the meaningful level of dependent variable $<0.05$ and the independent variable factor is negative, so it can concluded that Operating Expense Ratio as the proxy of agency cost have a negative significant on Z-score as the proxy of financial distress. It means if agency cost increasing, it will decrease the Z-score. On the contrary, If the agency cost decrease, it will increase the Z-score. 
The smaller of the amount of agency cost will impact the Z-score to be increase. This showed if the Z-score higher, it will means that the company is in the area no financial distress. This explain by Companies with scores above 3 are unlikely to enter bankruptcy. The result of second variable earning management have a negative impact on financial distress but not significant. It can said statistically that in term of decreasing earning management will increase financial distress but statically not significant. This research finding is partly support by the research of Qin (2017). Qin suggests that distress risk has more influence on earning management in companies that previously had positive earnings management. It means, if earning management of the company is positive or company do increase earnings management then company tends to decreasing earning management in the time of financial distress. As well the empirical result of Howe (2016), Habib et al. (2012) find that companies that experiencing distress will tend to manage earning upward.

\section{Conclusion}

This study examined the characteristics of earning management and agency cost by operating expense ratio and aimed to discover whether these variables have a significant relationship with the probability of companies get into financial distress. This empirical research was conducted using a sample of firms in Indonesian Capital Market from 2012 to 2016. The regression analysis used to test the hypothesis was applied only to the final sample of 22 firms at the end of the sample period from 2012 to 2016. This study used the Modified Jones Model to measure discretionary accruals. And the dependent variables Z-Score served as substitutes for financial distress. The hypothesis was tested using a regression model. The first independent variable operating expense ratio as substitutes the agency cost has a negative significant on financial distress. This result suggest that the smaller agency cost then Z-score greater meaning if the index of z-score is increasing means that the company included in the category of companies that do not tends to financial distress. As the agency cost has a negative significant on financial distress, investors should use the indicator of agency cost that is operating expense ratio to detect early signs of financial distress and take a precautions action in choosing the company for their investment.

Then, the second variable earning management has no relationship on financial distress. This result reveals that even if the company done upward and downward in managing the companies' earning, it would not cause the companies directly enter to the financial distress. Earning management slightly can be interpret as management 
behavior in maintain the company health. Although, there is no relationship between earning management and financial distress, it is suggested to the investors and financial analyst to pay attention to the management behavior of earning management. They should be sure whether the level of earning management in those companies is less than riskier to drag the company into financial distress. It is suggested to stock exchange authority and regulatory bodies to increase its attention in reducing the intended earning management.

\section{Funding}

This research is supported by the University of Sumatera Utara under the research grant TALENTA of Year 2018.

\section{References}

[1] Ang, R. A. Cole and J. W. Lin, (2000) "Agency Costs and Ownership Structure," Journal of Finance, Vol. 55, No. 1, 2000, pp. 81-106.

[2] Crutchley C E and R. S. Hansen, (1989) "A Test of the Agency Theory of Managerial Ownership, Corporate Leverage, and Corporate Dividends," Financial Management, Vol. 18, No. 5,1989, pp. 36-46.

[3] Dechow Patricia M and Douglas J. Skinner (2000) Earnings Management: Reconciling the Views of Accounting Academics, Practitioners, and Regulators. Accounting Horizons: June 2000, Vol. 14, No. 2, pp. 235-250.

[4] Habib, Ahsan; Md. Borhan Uddin Bhuiyan and Ainul Islan (2012) Financial distress, earnings management and market pricing of accruals during the global financial crisis, $11^{\text {th }}$ Auckland Regional Conference, $30^{\text {th }}$ November 2012, Auckland, New Zealand.

[5] Healy and Wahlen, 1999Healy, P. M., \& Wahlen, J. M. (1999). A review of the earnings management literature and its implications for standard setting. Accounting horizons, 13(4), 365-383.

[6] Howe, John S; Reza Houston (2016), Earning Management, Earning Surprise and Distress Firms, Accounting \& Finance Research vol.5 no.1,2016.

[7] Jensen Michael C and William H Meckling (1976), Theory of the Firm, Managerial Behavior, agency costs and Ownership Structure, Journal of Financial Economics (1976) 305-360. 
[8] Richardson, Vernon J (2000), information Asymmetry and Earning Management: some Evidence Review of Quantitative Finance and Accounting, 15 (2000): 325 3447 , 2000 Kluwer Academic Publishers. Manufactured in The Netherlands.

[9] Ross, S. A. - Westerfield, R. W. - Jaffe, J. (2005): Corporate Finance. New York, McGraw-Hill, 2005.

[10] Singh M and W. N. Davidson III, "Agency Costs, Ownership Structure and Corporate Governance Mechanisms," Journal of Banking and Finance, Vol. 27, 2003, pp. 793816.

[11] Wang, G.Y. 2010. The Impacts Of Free Cash Flow And Agency Cost On Firm Performance. Journal of Service Science And Management, vol. 3, no 4, pp 408-418.

[12] Qin, Zhongling, Xiao Ren (2017) Distress Risk and Earning Management. 